darf Grundtvig (wie auch andere) nicht einfach an heutigen Maßstäben messen. Inga Meincke zeigt Aspekte des Grundtvigschen Denkens, die uns heute fremd sind. Das ist verdienstvoll. Auch ist ihr zuzustimmen, daß man diese Seiten nicht einfach im apologetischen Interesse weginterpretieren darf. Aber deshalb ist die Aufgabe einer Aktualisierung und damit Umiterpretation bzw. Neuinterpretation noch nicht illegitim. Mag sein, daß Grundtvigs Reden von Muttersprache und Volk von Grundtvig viel enger als eine Metaphysik von der Überlegenheit dänischer Sprache und Kultur gemeint war, die Wirkungsgeschichte - gerade auch die internationale in der Heimvolkshochschulbewegung - zeigt aber, daß es durchaus legitim sein kann, Grundtvig mehr universell zu interpretieren. Mag sein, daß Grundtvig mit seinem Gedicht Mensch zuerst in Wirklichkeit Däne zuerst gemeint hat, aber es muß erlaubt sein, gerade dieses Gedicht auch universell zu interpretieren. Und daß das schöne Pfingstlied Var I ikke Galilaeer vor allem davon spricht, daß der Geist in der dänischen Muttersprache besonders wehe (V. 3, siehe S. 74, Anm. 311), mag vielleicht die Meinung Grundtvigs gewesen sein, macht aber eine universelle Deutung dieses Liedes nicht unmöglich. Muß nicht jede aktualisierende Interpretation, sei dies nun Luther, Kierkegaard oder Grundtvig, unterscheiden zwischen dem, was zeitbedingt ist an einem Autor und fremd, und dem, was sich aktualisieren läßt? Dabei ist auch bei einer mehr immanenten Grundtviginterpretation zu beachten, welchen Stellenwert die von der Autorin aufgezeigten problematischen Aspekte bei Grundtvig haben. Man darf die »totalitären« Aspekte bei Grundtvig nicht weginterpretieren - man darf sie aber auch nicht überinterpretieren, als habe Grundtvig immer nur die Überlegenheit dänischer Kultur und Sprache im Kopf, wenn er von Volk und Muttersprache redet. Man läuft dann auch Gefahr, die progressiven Seiten des grundtvigschen Erbes aus den Augen zu verlieren. So eindeutig ist die Sache vermutlich nicht: Auch die »linke« und progressive Grundtvigrezeption kann sich auf Grundtvigtexte berufen.

Wie dem auch sei: Trotz der These des Buches vom totalitären und autoritären Charakter des Grundtvigschen Werkes bin ich der Auffassung, daß Grundtvig heute Widerspruch und Kritik nicht nur ertragen kann, sondern auch braucht. Grundtvig ist vermutlich mit kritischer Aufmerksamkeit mehr gedient als mit platter Apologetik. Deshalb: Ein wichtiges und verdienstvolles Buch!

\title{
»Efterklang« som tolkningsnøgle
}

\section{Af Kim Arne Pedersen}

Anders Holm:Historie og Efterklang. En studie i N.F.S. Grundtvigs tidsskrift DanneVirke. Odense Universitetsforlag 2001. 139 sider. Pris: 175 kr.

Grundtvig-forskningen har i de senere år næsten umærkeligt oplevet en væsentlig ændring, når det gælder tilgangen til det store forfatterskab. Hvor den tidligere forskning overvejende forholdt sig positivt til Grundtvigs tankeverden, har man fra slutningen af 1990-erne kunnet opleve en langt mere kritisk holdning, knyttet til dels 
en drøftelse af Grundtvigs historiesyn (Knud Riis, Ole Vind) og dels diskussionen om Grundtvigs folkelighedsbegreb (Ove Korsgaard, Inga Meincke, Ole Vind o.a.), - det sidste under hensyntagen til den interesse for national identitet og nationalisme som ideologi, der siden murens fald og den europæiske union har præget intellektuelle miljøer $\mathrm{i}$ ind - og udland. Anders Holm danner her en væsentlig undtagelse ved overvejende at forholde sig positivt til Grundtvigs forfatterskab, idet han fokuserer på de lag heri, der kan siges at have gyldighed i en aktuel sammenhæng.

Anders Holms afhandling analyserer en række væsentlige tekster fra Grundtvigs tidsskrift »Danne-Virke« (DV) med henblik på at give en tolkning af Grundtvigs historiesyn, der fokuserer på den forholden sig til fortiden, som Anders Holm i forlængelse af Grundtvigs begrebsverden kalder for »efterklangsbevidstheden «. I forlagsomtalen betegnes afhandlingen som »en introduktion til en meget skelsættende periode i Grundtvigs liv og derfor et udgangspunkt for at forstå grundlæggelsen af nogle af de hovedtanker, som gennemtrænger det gigantiske forfatterskab«, og der tales om, at bogen binder Grundtvigs »digtning, ...teologi og ... historiesyn« sammen og viser, hvorledes de belyser hinanden. Det er store ord, men ikke for store, - der er virkelig tale om en væsentlig udgivelse, der imponerer, ikke mindst når det tages $\mathrm{i}$ betragtning, at bogen er en lettere omarbejdet udgave af en specialeafhandling ved Københavns Universitet, Det teologiske Fakultet. Det er let at se, hvad der berettiger til en udgivelse, noget, som kun overgår de færreste universitetsopgaver: afhandlingen bæres af en selvstændig nytolkning af materialet og er skrevet $i$ et klart sprog, der lader det samlende synspunkt fremstå tydeligt for læseren, ligesom de enkelte analyser præges af anskuelighed og fasthed i udformningen. Selvfølgelig kan der findes kritisable punkter i arbejdet. En del betydelig litteratur er ikke inddraget, eksempelvis William Michelsens drøftelser af Grundtvigs forholden sig til Kants tidsbegreb, Knud Bjarne Gjesings kommentararbejde til DV-afhandlingen »Om Mennesket i Verden« og Villiam Grønbæks bog om psykologiske tanker og teorier i Grundtvigs forfatterskab. Sine steder er forfatteren for unuanceret i sine domme, således, når han lader Grundtvig afvise »en fornuftsbaseret naturlig teologi« (s.80), men ikke nævner, hvad han selv dokumenterer, at Grundtvig arbejder med begrebet "naturlig åbenbaring" eller, når han med rette lader Grundtvig angribe "filosofisk systembyggeri« (s. 76) og »fornuftens autonomi eller den rene spekulative filosofi« ( s. 84), men i forlængelse heraf og påvirket af Helge Grells forskning dels lader Grundtvigs polemik mod Schelling blive ganske enerådende (s. 77), dels (s. 83) selv en smule inkonsekvent peger på, at Grundtvig arbejder med »ideale« forhold. Som helhed må bogen imidlertid opfattes som et væsentligt, nytolkende bidrag til udforskningen af Grundtvigs historiesyn, et værk, der vil blive stående i Grundtvig-litteraturen og kunne danne afsæt for en videre forskerkarriere.

Grundtvigs historiesyn kan ofte virke passé på en nutidig læser, præget som det er af tankeformer og ideer fra romantikken og - måske lige så væsentligt - århundrederne forud, den førmoderne, gammeleuropæiske, kristne tradition, som Grundtvig levede i, og som bevirker, at han selv lægger afstand til sin tids moderne tænkere: de førromantiske, idealistiske og romantiske skribenter, - også, selv om han selvfølgelig er stærkt præget af disse, således som det ofte er tilfældet med det, en skribent reagerer skarpt imod. Indenfor de senere år er der udkommet en stort anlagt undersøgelse af Grundtvigs historiesyn, der karakteriserer dette som præget af den fremskridtstro og udviklingsoptimisme, der karakteriserer anden halvdel af det 18. århundrede og 
begyndelsen af det 19. - jeg tænker her på Ole Vinds imponerende afhandling, hvor hovedvægten ligger på den modne Grundtvigs "Haandbog i Verdenshistorien «, men hvor også ungdomsværkerne tages op til behandling, og hvor eksempelvis Helge Toldbergs karakteristik af spejlingsmotivet i Grundtvigs digtning og historieskrivning benyttes som afsæt for en tolkning af Grundtvigs historiesyn som præget af en lineær tidsopfattelse, der i kraft af fokuseringen på udviklingsaspektet - måske ufrivilligt? - bliver bundet til årsag-virkningssammenhængene i universalhistorien. Anders Holm går en anden vej, omend hans brug af begrebet universalhistorie i en betydning, der ligger Ole Vinds Grundtvig-tolkning nær, kun fremgår en smule indirekte af s. 16, note 7 samt afslutningen s. 136. Anders Holm når frem til sin tese ved at inddrage og benytte en lang række forskerstandpunkter: når det gælder det overordnede perspektiv Erich Auerbach, Jakob Balling og Jørgen I. Jensen, når det gælder den specifikke DVforskning et bredt udvalg af Grundtvig-forskere: Poul Behrendt, Flemming LundgreenNielsen, Sune Auken o.a. Når Anders Holm inddrager sekundærlitteratur, sker det overvejende for at kunne tænke videre i forlængelse heraf. Bogens »lyttende" tone og den forsigtighed og omhu for detaljen, som udmærker hele afhandlingen, kommer ikke mindst til udtryk i de præcise referater af andre forskeres værker, referater, der glidende og naturligt, men dog samtidig markeret, videreføres i Anders Holms egne analyser. Væsentligt er her det forhold, at Anders Holm i sin tolkning af Grundtvigs historiesyn støtter sig på Erich Auerbachs fremstilling af den »typologiske anskuelse af historien«, der ligesom den universalhistoriske forløber indenfor en lineær tid, men afviger herfra på et væsentligt punkt. I »typologiens grundform« »peger to ting, der begge er sanselige og historiske, på hinanden « med Anders Holms egen gengivelse af et citat af Auerbach:

Figuralprofetien indeholder tydningen af én dennesidig hændelse ved hjælp af en anden; den første betyder den anden, den anden opfylder den første. Ganske vist forbliver begge historisk virkelige begivenheder; men for denne betragtning indeholder de alligevel begge noget foreløbigt og ufuldstændigt; de peger på hinanden, og begge peger på noget fremtidigt, som stadigvæk er i vente og først dér vil det egentlige, fuldt og virkeligt og endegyldigt indtræffe (s. 24).

\section{Det er Anders Holms opfattelse, at Grundtvig i DV begynder}

... at tale om historiske erfaringer, der unddrager sig den universalhistoriske betragtningsmåde. Der er ikke tale om, at historiske begivenheder er årsag til hinanden, men at de spejler hinanden. Typologien har nemlig,som Auerbach peger på i forhold til hændelser med en horisontal historieopfattelse, et vertikalt perspektiv (s. 26-27).

Auerbachs analyse af figuraltolkningen forbinder Anders Holm med den filosofiske hermeneutik, som den er udformet af bl.a. Hans-Georg Gadamer. Her er der tale om en sammenhæng, der kun delvis er synlig i arbejdet, og som læser savner man en uddybet redegørelse for forbindelserne. En væsentlig inspirationskilde for Anders Holm er utvivlsomt Jørgen I. Jensen, således, når Holm modstiller »to forskellige tids - eller luftrejser: En hvor man så at sige benytter sig af rekonstruktiv teknik og en, hvor man ser nutiden med fortidens øjne« og med henblik på Grundtvigs tolkning af 
opstandelsen i »Paaske-Lilien« skriver, at »Fritaget fra at skulle gætte sig tilbage gennem en meget usikker rekonstruktion af historien påvirkes mennesket af dette fortidige til tro« (s. 121). Grundtvigs »tidsbevægelse()« er "at gå tilbage til udgangspunktet selv og herfra se mod fremtiden og ikke omvendt" (s. 121), noget, der ifølge Anders Holm ikke lader sig gennemføre »inden for en universalhistorisk bevidsthed" (s. 121).

Til Auerbach og hermeneutikken føjer sig positioner i Grundtvigforskningen, og her gør Anders Holm en væsentlig undtagelse i forhold til sit lyttende princip, idet han tager stilling til to fremtrædende litteraturforskere, der begge har beskæftiget sig med efterklangs-begrebet i Danne-Virke: Poul Behrendt og Flemming Lundgreen-Nielsen. Anders Holm slutter sig til den førstnævnte og gennemfører på baggrund heraf en eksplicit, men sober kritik af den anden, hvis enestående og grundige forskningsindsats han også trækker på bogen igennem. Præcist gør Anders Holm til indledning rede for efterklangsgenren, idet han slår fast, at

En efterklang er et digt, der er skrevet til fortiden. Først lod Grundtvig trykke en inspirationstekst som kunne være en folkevise, en gammel saga eller et gammelt sagn. Derpå gav han sin egen poetiske udlægning heraf, et digt som han kaldte efterklang. Efterklangen kunne variere fra at være et næsten direkte referat af teksten, historien, til at være en tolkning eller udlægning af teksten som profeti. eller bare til at være udtryk for de følelser, inspirationsteksten umiddelbart vakt (s. 31)

Diskussionen med de to Grundtvig-forskere drejer sig nu om, hvorvidt efterklangs begrebet med Lundgreen-Nielsen skal defineres snævert, alene knyttet til de digte Grundtvig lader genren omfatte, eller om man med Behrendt kan udstrække begrebe "som et godt dækkende ord for hele digtningens stofskifte i perioden" (s. 32). Ander: Holm tilslutter sig Behrendt, idet han gennem en analyse af den digtning, der faldes direkte ind under begrebet, når frem til, at »efterklangen er et eksempel på, at gendigt. ning af situationer, blot i kraft af at sætte digteren i kontakt med en hændelse fortiden, kan falde ind under genrebetegnelsen« (s. 69). Prægnant kan Anders Holm derfor skrive, at læseren og han ser, »at en gammel begivenhed kan få en ny forkla. relse « (s. 69), der er tale om en bevægelse, der kan bestemmes som »typologisk «, ide »en fjern hændelse i fortiden ... pludselig (har) betydning i nutiden, hvilket gør el spring eller en overflyvning af historien mulig" (s. 111). Bevægelsen rummer i sir knappe formulering netop det træk, der gør det muligt for Anders Holm at kontraster figuraltolkningen og den universalhistoriske betragtningsmåde. Den tidsopfattelse, der giver sig af Anders Holms udnyttelse af figuraltolkning og efterklangsbevidsthed genfindes i »den hermeneutiske cirkel « (s. 57): Grundtvig griber i sin fremadrettethed tilbage til fortiden og bliver derved i stand til at fortolke nutiden. Den typologiske betragtningsmåde rummer, som ovenfor nævnt, et vertikalt perspektiv, hvorimod universalhistoriens horisontale perspektiv giver sig af den fortolkning af fremtiden som resultat af en proces i forhold til de kim, der ligger i fortiden.

Dette forhold kommer tydeligst til udtryk i Anders Holms konkrete analyse af "Paaske-Lilien«. Afhandlingens »medtænkende«, men også bevidst aktualiserende præg fremstår af det forhold, at Anders Holm her modstiller den »selvpræstere(de) religiøs(e) meditationsøvelse» og det at »flyve med historien«, historien tolket som 
»den kollektive erfarings vej i stedet for det subjektive sværmeri« (s. 120), medtænkende både $\mathrm{i}$ den forstand, at Grundtvigs egen fordømmende holdning til sin samtids idealistiske og romantiske tænkning og digtning fastholdes, uden at Anders Holm spørger, om ikke tanken om historien som den kollektive erfaring kan opfattes som en genuin romantisk tankeform, og medtænkende i og med, at Anders Holm som før nævnt ikke forholder sig negativt til Grundtvigs tankeverden. Forskellen træder markant frem, i det øjeblik, man forsøger at profilere tolkningen ved at inddrage forskning med en anden tilgang. Med fare for at tillægge Ole Vind forkerte synspunkter ville en fortolkning i overensstemmelse med dennes tese i stedet fokusere på det forhold, at Grundtvig forventer historiens " genopstandelse « i den nære fremtid, læs: optimistisk regner med en udvikling, der fører den menneskelige erkendelse videre. Ole Vinds anliggende ville her overordnet være at pege på udviklingsoptimismen og fremskridtstroen i Grundtvigs historiesyn, sekundært at fæstne sig ved, hvad han selv betegner som Grundtvigs »åndshistorisk(e) antropologi« (Ole Vind, Grundtvigs Historiefilosofi s. 558ff.), dvs. opfattelsen af mennesket som et historisk væsen, afhængigt og formet af de foregående slægters indflydelse og givende kulturarven videre til det næstfølgende slægtled. Nu kunne en "samtale« mellem de to Grundtvig-forskere knytte til netop ved denne tanke, som Vind selv forbinder med Hans-Georg Gadamers filosofiske hermeneutik. Men i Ole Vinds værk som helhed, og i præsentationen af værkets tese fokuseres der netop på de elementer i Grundtvigs historiesyn, der gør det utidssvarende. Grundtvig har selv i en tidlig tekst giort det klart, at historien for ham fører menneskeslægten frem til indsigt $i$, hvad der gør mennesket til menneske, dvs. indsigt i dets bestemmelse og mål (N.F.S. Grundtvig, Værker i Udvalg v. Hal Koch og Georg Christensen, I-X, III, s. 262), og i en vis forstand forsøger Vind da også at videreføre og aktualisere dette anliggende. For Vind skygger Grundtvigs historiesyn i sin konkrete, indholdsmæssige udformning imidlertid for det, der stadig kan siges at have gyldighed. At en fortolkning bygger på udvælgelse, og at Anders Holm bevidst vælger de "problematiske« sider af Grundtvig fra, er både afhandlingens styrke og svaghed. Dette kommer ikke blot til udtryk i sammenhæng med diskussionen om universalhistorie-typologi, hvor Anders Holm eksplicit gør rede for de to lag i forfatterskabet, men kommer også til udtryk i hans yderst rimelige fremhævelse af, at Grundtvig fastholder tanken om »menneskehedens åndelige slægtskab« (s. 86), der samtidig blokerer for en kritisk diskussion af danskhedsbegrebets rolle i forfatterskabet. Endelig ses denne svaghed også i Anders Holms løbende inddragelse af andre forskningspositioner. Således underbelyses i analysen af »Paaske-Lilien« den selvsymbolik, som Fl. Lundgreen-Nielsen har peget på, til fordel for spørgsmål om, hvorvidt »man kan levendegøre historien« (s. 118). Ligesom det gælder forholdet mellem en tolkning af Grundtvigs historiesyn, der fokuserer på de universalhistoriske træk heri, og Anders Holms udnyttelse af typologimotivet til at pege på historiens »udlæggende« karakter, gør det sig også her gældende, at én side af Grundtvigs tankeverden næsten forsvinder, eller i hvert fald tenderer mod at miste sin betydning: selvsymbolikken er kun væsentlig, i og med, at den indføjes i tanken om, at historien selv er fortolkende i forhold til det subjekt, der så fungerer som formidler heraf. Andre sider af afhandlingen kunne her fremdrages: Anders Holms konkrete fortolkninger af efterklangsgenren, dvs. de enkelte efterklangsdigte, overbeviser ved deres grundighed og hele fornemmelse for Grundtvigs tankeverden, men dermed bliver man som læser ikke overbevist om digtenes aktualitet, når det 
gælder deres konkrete indhold. Dybest set er det kun hans fortolkning af »PaaskeLilien «, der bider sig fast $\mathrm{i}$ læserens bevidsthed som en virkelig nutidigt vedkommende tekst, ganske simpelt fordi dette digt løst ud af sin sammenhæng med det mysteriespil, hvori det er indføjet, med rette er blevet en klassiker i dansk litteratur. At dette er tilfældet, skyldes digtets egne kvaliteter $i$ henseende til form og først og fremmest indhold. Pointen i Anders Holms fortolkning er lig med hele det hermeneutiske aspekt af den typologiske fortolkningsmåde: det forhold, at »det fortidige kan opstå i det nutidige« (s. 75). »Paaske-Lilien« handler ganske enkelt om dette forhold, og eftersom opstandelsesmotivet er det centrale heri, falder digtets indhold og den filosofiske hermeneutiks analyse af menneskets forholden sig til historien godt sammen. Og med "Paaske-Lilien« som udgangspunkt lukker resten af DV-forfatterskabet sig selvfølgelig op, - og læseren sidder tilbage, klogere på en tidlig periode i Grundtvigs liv og med ønsket om, at undersøgelsen følges op af tolkninger af de senere, klassiske tekster i Grundtvigs store forfatterskab. I en tid, hvor Grundtvig-kritikken făr uforholdsmæssig stor betydning, er det velgørende, at yngre forskere tager forfatterskabet op med en anderledes, og langt mere positiv indfaldsvinkel.

\section{Den mageløse Grundtvig}

\section{Af Jørgen Carlsen}

A. M. Allchin, S. A. J. Bradley, N. A. Hjelm, J. H. Schjørring ed.: Grundtvig in International Perspective. Studies in the Creativity of Interaction. Aarhus University Press, Gylling 2000, ISBN 877288835 0. 209 s.

"One cannot help feeling, that there is something strange about this man. He is more scholarly than the scholars and more popular than the publicists. He does not like to fit into our usual ways of categorising people, even of categorising people of exceptional ability and vision.« (s. 6).

Således lyder A.M. Allchins indledende karakteristik af N. F. S. Grundtvig i bogen »Grundtvig in International Perspective«, der udkom sidste år som det 33. bind $i$ rækken af skrifter, udgivet af Grundtvig-Selskabet. Bag udgivelsen står foruden hovedredaktøren A.M. Allchin (professor ved University College of North Wales i Bangor, UK), S.A.J. Bradley (docent ved University of York, England), Norman A. Hjelm (præst Wynnewood, Philadelphia, USA) og teologen Jens Holger Schjørring (professor ved Århus Universitet).

Udgivelsen kan ses som en slags follow-up på en tidligere engelsksproget antologi af samme karakter. I 1993 udgav Grundtvig-Selskabet bogen »Heritage and Prophecy « - også dengang redigeret af A.M. Allchin og Jens Holger Schjørring i selskab med andre. Denne antologi havde undertitlen: »Grundtvig and the Englisch-Speaking World«. Som man vil kunne ane, er der en påfaldende glidning i perspektivet fra den første til denne anden udgivelse »Grundtvig in International Perspective«. Vi bevæger os fra det engelsk-sprogede domæne videre ud i verden. Dermed er der også anslået et skjult 